\title{
Feeding Artemia nauplii enriched with the probiotic bacterium Bacillus subtilis improved growth performance, survival and digestive enzyme activity of Clarias batrachus (Linnaeus, 1758) larvae
}

\author{
S. P. KAMBLE ${ }^{1}$, A. K. SAHU ${ }^{2}$, S. MOHANTY ${ }^{2}$, S. K. SAHOO ${ }^{2}$, K. MURMU ${ }^{2}$, CHANDRA PRAKASH ${ }^{3}$ \\ AND N. K. CHADHA ${ }^{3}$ \\ ${ }^{1}$ Regional Research Centre of ICAR-Central Inland Fisheries Research Institute, Harni road, Vadodara - 390022 \\ Gujarat, India \\ ${ }^{2} I C A R$-Central Institute of Freshwater Aquaculture, Kausalyaganga, Bhubaneswar - 751 002, Odisha, India \\ ${ }^{3}$ ICAR-Central Institute of Fisheries Education, Mumbai - 400 061, Maharashtra, India \\ e-mail: suhaskamble149@gmail.com
}

\section{ABSTRACT}

\begin{abstract}
Clarias batrachus (Linnaeus, 1758) larvae were subjected to different modes of probiotic (Bacillus subtilis) administration such as: T1: feeding Artemia nauplii enriched with B. subtilis; T2: feeding enriched Artemia nauplii + addition of B. subtilis in water and T3: addition of $B$. subtilis in water alone, for a period of 14 days. A control group (T0) with no probiotic administration was also maintained. On termination of the experiment, probiotic supplemented through enriched Artemia nauplii along with addition in water $(\mathrm{T} 2)$ yielded significantly $(\mathrm{p}<0.05)$ higher length, weight, weight gain, specific growth rate and survival compared to control (T0) and T3 groups. All these parameters did not differ significantly ( $\mathrm{p}>0.05)$ between $\mathrm{T} 1$ and T2. Similar trend was observed in the case of total gut bacterial count and digestive enzyme activity. The highest $(p<0.05)$ digestive enzyme activity of protease, lipase and amylase were recorded in $\mathrm{T} 2$, while no significant $(\mathrm{p}>0.05)$ difference was observed between T2 and T1. The present study reiterated the advantage of B. subtilis, and its administration through enriched Artemia nauplii which could be a promising supplementation mode during C. batrachus larval rearing.
\end{abstract}

Keywords: Growth, Larval rearing, Magur, Probiotic, Survival

Asian catfish Clarias batrachus (Linnaeus, 1758) is one of the promising cultivable air-breathing catfish in Asian countries and considered as a candidate species for aquaculture diversification. Major attributes of this species are its hardy nature which can withstand adverse ecological conditions, response to high density culture and high yielding capacity. Thus it has great potential for grow-out culture in ponds (Thakur, 1986, Areerat, 1987, Sahoo et al., 2008). But the major bottleneck is the lack of availability of seed in sufficient quantity for commercial farming. Early mortality of larvae in hatchery is the major hurdle which is attributed to improper nutrition, poor water quality and outbreak of diseases (Sinha et al., 2014). Presently probiotics are increasingly being utilised in aquaculture for improving disease resistance, growth as well as feed utilisation efficiency (Balcazar et al., 2006, Sahu et al., 2008, Martinez Cruz et al., 2012, Hai, 2015b). Accumulated evidence suggest that, probiotics aid to improve water quality, digestibility of nutrients, control of bacterial infections, tolerance to biotic/abiotic stress and reproduction (Sahu et al., 2008, Ninawe and Selvin, 2009, Behera and Nayak, 2011, Martinez Cruz et al., 2012). The commonly used probiotics in aquaculture sector belong to the genera, Lactobacillus, Bacillus, Leuconostoc, Lactococcus, Aeromonas, Enterococcus, Carnobacterium, Shewanella, Pseudomonas, Enterobacter, Clostridium and Saccharomyces (Balcazar et al., 2006, Hai, 2015b, Kumar and Ghosh, 2016). Thus, probiotics are becoming a vital part in the aquaculture industry. Gut microbiota of fishes can be manipulated using probiotics i.e., beneficial microbiota for enhancing nutritional efficiency as well as immunity against diseases (Balcazar et al., 2006, Farzanfar, 2006, Akhter et al., 2015, Hai, 2015a, b).

Various microbes have been investigated as probiotics for aquaculture of which several species belonging to the genus Bacillus have been found helpful to produce proteases and other enzymes that contribute to the natural digestion activity of the host (Ziaei-Nejad et al., 2006; Cutting, 2011; Nimrat et al., 2012a). Bacillus spp. have been found to act as source of micro and macroelements in feed (Verschuere et al., 2000) and have also been found to enhance survival, growth as well as improve water quality in terms of bioremediation (Cutting, 2011; Hai, 2015b). Bacillus subtilis is well known to prevent 
colonisation of potential pathogens in the gut of host organisms, through the production of antimicrobial compounds, or by actively competing for nutrients/space (Nayak, 2010; Sumathi et al., 2014).

Though the beneficial effects of environment friendly probiotics in aquaculture are well documented, there is no information on the probiotic effects of Bacillus spp. in the larvae of Asian catfish C. batrachus. Therefore, the present study aimed to determine the effects of B. subtilis and its mode of administration on the growth, survival and digestive enzyme of $C$. batrachus larvae.

Pure bacterial strain of B. subtilis (MTCC 441) was procured from Microbial Type Culture Collection (MTCC), Institute of Microbial Technology (IMTECH), Chandigarh, India. Bacterial culture was inoculated into conical flask containing nutrient broth (HiMedia) and incubated at $30^{\circ} \mathrm{C}$ for $24 \mathrm{~h}$ (APHA, 1998). For enrichment of Artemia nauplii, the broth culture was centrifuged (Eppendorf, 5810R) at $2500 \mathrm{~g}$ for $30 \mathrm{~min}$ at $4^{\circ} \mathrm{C}$. The pellet was washed thrice with sterile phosphate buffered saline (PBS, pH 7.2) and re-suspended in PBS. The bacterial concentration was adjusted to desired level using serial dilution method (Kumar et al., 2013) and measuring optical density (OD600) by spectrophotometry (Lamda 25 UV-VIS spectrometer, Perkin Elmer). Hatching of Artemia cysts and its enrichment with probiotics was carried out as suggested by Sorgeloos et al. (1986). After hatching, nauplii were transferred to fresh saline water of $12 \%$ in 61 capacity glass jar for enrichment. The daily requirement of Artemia nauplii were calculated and the probiotic bacteria (B. subtilis) were added to the enrichment medium at a cell density of $1.5 \times 10^{6} \mathrm{cfu} \mathrm{ml}^{-1}$. Enrichment was done for a period of $6 \mathrm{~h}$. Vigorous aeration was provided in the glass jar to ensure thorough mixing and to keep Artemia cysts/nauplii in suspension. After enrichment, Artemia nauplii were collected using bolting silk cloth and fed to the larvae in the experimental groups.

C. batrachus larvae were obtained by induced breeding techniques in the catfish hatchery of ICAR-Central Institute of Freshwater Aquaculture (ICAR-CIFA), Bhubaneswar, India. Twelve uniform sized glass aquaria (30 1 capacity) were used for the study. Total volume of water in the glass aquaria was maintained at 101 to maintain a water height of 6 inches throughout the experimental period, The glass aquaria were uniformly filled with 101 water and were provided with continuous aeration. Four days old larvae of $9 \pm 0.2 \mathrm{~mm}$ length and $4.68 \pm 0.08$ mg weight were stocked @ 11 nos. $1^{-1}$ randomly into the 12 aquaria. Larvae of $C$. batrachus were subjected to different modes of probiotic (B. subtilis) feeding with three replicates each, such as: T0 - control with no probiotic administration; T1: Artemia nauplii enriched with B. subtilis; T2: Artemia nauplii enriched with $B$. subtilis + addition of B. subtilis in water and T3: addition of $B$. subtilis in water. Enrichment of Artemia nauplii with above mentioned probiotic bacteria was done at a concentration of $1.5 \times 10^{6} \mathrm{cfu} \mathrm{ml}^{-1}$ of enrichment medium while application of probiotic bacteria in water was done at concentration of $1.5 \times 10^{6} \mathrm{cfu} \mathrm{ml}^{-1}$ of rearing water per day. The larvae were fed ad libitum as per the treatments while larvae in control and T3 were fed with normal Artemia nauplii over a period of 14 days. The experimental tanks were cleaned once daily and $75 \%$ water was exchanged (before feeding and addition of probiotic bacteria) without much disturbance to the larvae.

To study the efficacy of B. subtilis, the total bacterial count in gut of the larvae was examined on day 1, 7 and 14 of the experiment. At each sampling, five larvae from each aquaria were randomly selected and surface disinfected with alcohol, washed in sterile distilled water and dissected to collect gut. Gut samples collected form each treatment were pooled, weighed and homogenised in $5 \mathrm{ml}$ of sterile normal saline solution $(0.85 \% \mathrm{w} / \mathrm{v} \mathrm{NaCl})$. Enumeration of total bacterial count was performed by serial dilution and plating on brain heart infusion (BHI) agar (Himedia) plates. The plates were incubated at $28^{\circ} \mathrm{C}$ for $24-48 \mathrm{~h}$ in BOD incubator followed by counting of bacterial colonies.

Growth performance of the larvae in terms of percentage length and weight gain, specific growth rate (SGR) and survival rate were estimated using the following formulae:

$$
\begin{array}{ll}
\text { Length gain } \%= & \text { (Final length }- \text { Initial } \\
& \text { length }) \times 100 / \text { Initial length } \\
= & \text { (Final weight }- \text { Initial weight }) \\
& \times 100 / \text { Initial weight }
\end{array}
$$

For assay of the digestive enzyme activity, 55 fry per aquaria were collected on termination of the experiment and then immediately frozen at $-70^{\circ} \mathrm{C}$ until enzyme assays were performed. Approximately $1.0 \mathrm{~g}$ of whole fry were homogenised in chilled 10 mMTris $\mathrm{HCl}$ buffer at $\mathrm{pH} 7.5$ and enzyme extracts were obtained after centrifugation at $10,000 \mathrm{~g}$ for $30 \mathrm{~min}$ at $4^{\circ} \mathrm{C}$. The supernatant of each sample was assayed in triplicate. Bradford (1976) method was used to measure total soluble protein using bovine serum albumin as a standard. Amylase activity was assayed by the method of Bernfeld (1955) using 
3,5-dinitrosalicylic acid with soluble starch as the substrate. Total protease activity was assayed according to the method of Anson (1938), using Folin's reagent with casein as the substrate. Lipase activity was determined following Cherry and Crandell (1932). Enzyme activities were measured as the change in the absorbance using a PerkinElmer, Lamda25 UV-VIS spectrometer.

Water samples from each aquaria were taken periodically between 07.00 and $08.00 \mathrm{hrs}$ every alternate days before cleaning. The water quality parameters such as $\mathrm{pH}$, total alkalinity, free $\mathrm{CO}_{2}$, ammonia nitrogen, nitritenitrogen and nitrate-nitrogen were analysed following APHA (1998). Water temperature and dissolved oxygen were recorded daily with a dissolved oxygen meter (MERCK, Germany).

The data on the growth performance and survival were subjected to statistical analysis using SPSS v.16. One-way analysis of variance was used to compare all the treatments. Duncan's multiple range test was performed at $95 \%$ significance level to compare the treatment means for different parameters.

There was no significant difference in the physicochemical parameters of water between control and treatment aquaria $(\mathrm{p}>0.05)$. Water temperature $\left({ }^{\circ} \mathrm{C}\right)$, dissolved oxygen $\left(\mathrm{mg} \mathrm{l}^{-1}\right)$, $\mathrm{pH}$, total alkalinity, ammonianitrogen, nitrite-nitrogen and nitrate-nitrogen ranged from $27.5-28.8^{0} \mathrm{C}, 6.2$ to $7.1 \mathrm{mg} \mathrm{l^{-1 }}, 7.48$ to $8.19,110$ to $130 \mathrm{mg} \mathrm{l}^{-1}, 0.16$ to $0.37 \mathrm{mg} \mathrm{l}^{-1}, 0.001$ to $0.007 \mathrm{mg} \mathrm{l}^{-1}$ and 0.003 to $0.023 \mathrm{mg} \mathrm{l}^{-1}$ respectively. Values observed in this study were within the optimum range for C. batrachus as reported by Rao et al. (1994).

The probiotic potential of $B$. subtilis was evident from the higher survival and growth performance in terms of final length, final weight, \% weight gain and SGR of C. batrachus fry in the $B$. subtilis supplemented treatments over non-supplemented group (Control) $(p<0.05)$ (Table 1). Similarly, earlier studies demonstrated improvement in larval growth and survival with B. subtilis supplementation in Macrobrachium rosenbergii (Seenivasan, et al., 2012), Penaeus vannamei (Nimrat et al., 2012a), Penaeus monodon (Nimrat et al., 2012b), Sparus aurata (Nihan et al., 2013) and Heteropneustes fossilis (Ramakrishnan, et al., 2015). Supplementation through enriched Artemia nauplii and addition in water (T2) yielded significantly high survival and growth in terms of length, weight, \% weight gain and SGR compared to control (T0) and T3. Statistically similar $(\mathrm{p}>0.05)$ results were obtained between $B$. subtilis supplemented through enriched Artemia nauplii (T1) and T2. Suzer et al. (2008) reported increased growth and survival of seabream, S. aurata larvae supplemented Lactobacillus spp. through live feed with water in the same environment. Similar results were reported in the Persian sturgeon, Acipenser persicus larvae (Faramarzi et al., 2011), seabream larvae (Avella et al., 2010) and M. rosenbergii larvae (Keysami et al., 2007). However, Ziaei-Nejadand et al. (2006) reported that growth performance and survival were not significantly different between Bacillus spp. administered through Artemia enrichment and addition to water. The improved growth performance and survival of C. batrachus larvae in T2 and T1 might be due to the colonisation of probiotic bacteria in the gut of Artemia nauplii and transition to larval fish intestine after digestion (Suzer et al., 2008). Moreover in the present work, larvae in group T3 administered with probiotics in the rearing water showed significantly higher growth and survival compared to control (T0), which is in line with the results from the earlier studies on Clarias gariepinus larvae (Ariole, 2012), tilapia, Oreochromis niloticus (Wang et al., 2008, Zhou et al., 2010), large yellow croaker Larimichthys crocea (Ai et al., 2011), grouper Epinephelus coioides (Sun et al., 2010) and shrimp P. vannamei larvae (Zhou et al., 2009, Liu et al., 2010). Increased growth in larvae fed with B. subtilis could be attributed to improved digestive activity which is evident from the increased digestive enzyme activity in B. subtilis supplemented treatments (Keysami et al., 2012).

The functionality of probiotic strain depends on its gut colonisation potential (Walker and Duffy 1998; Balcazar et al., 2006). In the present study, total bacterial counts recorded in the gut of $C$. batrachus

Table 1. Yield attributes of $C$. batrachus fry supplemented with B. subtilis through different modes (means \pm S.E, $\mathrm{n}=3$ )

\begin{tabular}{llllll}
\hline Treatment & \multicolumn{5}{c}{ Growth parameter } \\
\cline { 2 - 6 } & FL $(\mathrm{mm})$ & FW $(\mathrm{mg})$ & WG $(\%)$ & SGR $\left(\% \mathrm{~d}^{-1}\right)$ & Survival $(\%)$ \\
\hline Control (T0) & $14.51 \pm 0.06^{\mathrm{a}}$ & $18.85 \pm 0.2^{\mathrm{a}}$ & $318.81 \pm 6.39^{\mathrm{a}}$ & $9.96 \pm 0.1^{\mathrm{a}}$ & $76.41 \pm 1.4^{\mathrm{a}}$ \\
T1 & $16.00 \pm 0.08^{\mathrm{c}}$ & $27.52 \pm 0.30^{\mathrm{c}}$ & $511.49 \pm 6.62^{\mathrm{c}}$ & $12.83 \pm 0.07^{\mathrm{c}}$ & $86.92 \pm 1.33^{\mathrm{c}}$ \\
T2 & $16.00 \pm 0.04^{\mathrm{c}}$ & $27.84 \pm 0.19^{\mathrm{c}}$ & $518.69 \pm 4.15^{\mathrm{c}}$ & $12.92 \pm 0.04^{\mathrm{c}}$ & $88.21 \pm 0.68^{\mathrm{c}}$ \\
T3 & $14.93 \pm 0.10^{\mathrm{b}}$ & $21.94 \pm 0.14^{\mathrm{b}}$ & $387.54 \pm 3.13^{\mathrm{b}}$ & $11.10 \pm 0.03^{\mathrm{b}}$ & $81.79 \pm 1.36^{\mathrm{b}}$ \\
\hline
\end{tabular}

Values in the same column sharing a common superscript are not significantly different $(\mathrm{p}>0.05)$

FL: Final total length, FW: Final weight, WG: Weight gain, SGR: Specific growth rate 
larvae supplemented with $B$. subtilis through different modes, on day 1, 7 and 14 of larval rearing are shown in Table 2. Significant increase in total gut bacterial count was observed in all the treatments during day 1 to 14 . Except for the day 1, subsequent samplings on day 7 and 14 showed significantly high total gut bacterial count in group T2 supplemented with $B$. subtilis through enriched Artemia nauplii and addition in water compared to the control (T0) and group T3 supplemented with B. subtilis by addition in water. There was no significant difference in total gut bacterial count between T2 and T1 ( $>0.05)$. Significant increase in total gut bacterial count in B. subtilis supplemented groups observed in the present study suggests that, B. subtilis successfully colonised in the gut of $C$. batrachus fry and might have led to improved survival by preventing colonisation of potential pathogens through the production of antimicrobial compounds, or by actively competing for nutrients or space (Nayak, 2010; Sumathi et al., 2014). Similar results were reported in $M$. rosenbergii using B. subtilis as a probiotic (Keysami et al., 2012).

Several researchers have demonstrated that one of the main modes of action and beneficial effects of probiotics in aquatic organisms is the enhancement of nutrition of host species via the production of supplemental digestive enzymes (Verschuere et al., 2000; Martinez Cruz et al., 2012). Bacteria particularly members of the genus Bacillus are known to produce a wide range of exoenzymes (Moriarty, 1996, 1998). In the present study, the activity of digestive enzymes such as protease, lipase and amylase were significantly elevated $(\mathrm{p}<0.05)$ in treatment groups supplemented with B. subtilis (Table 3). Earlier studies have also reported enhanced digestive enzyme activity with supplementation of Bacillus probiotics in Cyprinus carpio (Yanbo and Zirong, 2006), Penaeus indicus larvae (Ziaei-Nejad et al., 2006), P. vannamei larvae (Zhou et al., 2009, Nimrat et al., 2012a) and seabream, S. aurata larvae (Nihan et al., 2013). Digestive enzyme activities were enhanced in all the experimental groups supplemented

Table 2. Total bacterial count (CFU x $\left.10^{4}\right)$ in the gut of $C$. batrachus fry supplemented with $B$. subtilis through different modes (Means \pm SE, $n=3$ )

\begin{tabular}{llll}
\hline \multirow{2}{*}{ Treatment } & \multicolumn{3}{c}{ Total bacterial count $\left(\mathrm{CFU} \times 10^{4}\right)$ per fish } \\
\cline { 2 - 4 } & Day 1 & Day 2 & Day 14 \\
\hline Control (T0) & $7.89 \pm 0.73^{\mathrm{aA}}$ & $11.00 \pm 1.01^{\mathrm{bA}}$ & $14.22 \pm 0.80^{\mathrm{cA}}$ \\
T1 & $8.11 \pm 0.11^{\mathrm{aA}}$ & $23.33 \pm 0.51^{\mathrm{bC}}$ & $35.89 \pm 2.00^{\mathrm{cC}}$ \\
T2 & $7.67 \pm 0.66^{\mathrm{aA}}$ & $24.67 \pm 0.33^{\mathrm{bC}}$ & $36.22 \pm 1.32^{\mathrm{cC}}$ \\
T3 & $7.33 \pm 0.19^{\mathrm{aA}}$ & $19.22 \pm 1.45^{\mathrm{bB}}$ & $24.00 \pm 1.02^{\mathrm{cB}}$ \\
\hline
\end{tabular}

Values in the same row sharing common lowercase superscripts are not significantly different $(p>0.05)$ and values in the same column sharing common uppercase superscripts are not significantly different $(p>0.05)$
Table 3. Digestive enzyme activity of $C$. batrachus fry supplemented with B. subtilis through different modes (Means \pm S.E, $\mathrm{n}=3$ )

\begin{tabular}{|c|c|c|c|}
\hline \multirow{2}{*}{ Treatment } & \multicolumn{3}{|c|}{ Digestive enzymes ( $\mathrm{U}$ mg Protein $^{-1}$ ) } \\
\hline & Protease & Lipase & Amylase \\
\hline Control (T0) & $0.751 \pm 0.045^{\mathrm{a}}$ & $0.412 \pm 0.033^{\mathrm{a}}$ & $0.339 \pm 0.0137^{\mathrm{a}}$ \\
\hline $\mathrm{T} 1$ & $1.190 \pm 0.032^{\mathrm{c}}$ & $0.623 \pm 0.014^{\mathrm{c}}$ & $0.549 \pm 0.0039^{c}$ \\
\hline $\mathrm{T} 2$ & $1.279 \pm 0.077^{\mathrm{c}}$ & $0.638 \pm 0.007^{\mathrm{c}}$ & $0.563 \pm 0.023^{\mathrm{c}}$ \\
\hline T3 & $0.919 \pm 0.051^{\mathrm{b}}$ & $0.549 \pm 0.002^{\mathrm{b}}$ & $0.482 \pm 0.005^{\mathrm{b}}$ \\
\hline
\end{tabular}

Values in the same column sharing common superscripts are not significantly different $(\mathrm{p}>0.05)$

with probiotics. But, the mode of administration of probiotics to the larval fish strongly affected the enzymatic activity (Suzer et al., 2008). In the present work, increased digestive enzyme activities (protease, lipase and amylase) were significantly higher $(\mathrm{p}<0.05)$ in $\mathrm{T} 2$, compared to control (T0) and T3. However, no significant difference $(p>0.05)$ was observed between T2 and T1. Significantly enhanced digestive enzyme activity $(\mathrm{p}<0.05)$ was observed in $\mathrm{T} 2$ and $\mathrm{T} 1$ compared to $\mathrm{T} 3$ and $\mathrm{T} 0$. However, the digestive enzyme activity in T3 was significantly higher than control T0. This is in agreement with earlier study in P. vannamei larvae, which received probiotic Bacillus coagulans directly in rearing water (Zhou et al., 2009).

In conclusion, the present study while reiterated the advantages of $B$. subtilis supplementation in larval rearing of $C$. batrachus. The results also revealed that administration of $B$. subtilis through enriched Artemia nauplii to be better and economical over administration of only B. subtilis in water or application of enriched Artemia nauplii along with addition of $B$. subtilis in water.

\section{Acknowledgements}

We are thankful to the Director and Joint Director, ICAR-CIFE, Mumbai, India for their co-operation and encouragement during this study. Authors also express their sincere thanks to the Director, ICAR-CIFA, Bhubaneswar, India for necessary facilities provided for the study.

\section{References}

Ai, Q., Xu, H., Mai, K., Xu, W., Wang, J. and Zhang, W. 2011. Effects of dietary supplementation of Bacillus subtilis and fructooligosaccharide on growth performance, survival, non-specific immune response and disease resistance of juvenile large yellow croaker, Larimichthys crocea. Aquaculture, 317: 155-161. DOI: 10.1016/j.aquaculture. 2011.04.036.

Akhter, N., Wu, B., Memon, A. M. and Mohsin, M. 2015. Probiotics and prebiotics associated with aquaculture: A review. Fish Shellfish Immunol., 45: 733-741. DOI: 10.10 16/j.fsi.2015.05.038. 
Anson, M. L. 1938. The estimation of pepsin, trypsin, papain and cathepsin with haemoglobin. J. Gen. Physiol., 22: 79-89. DOI: $10.1085 /$ jgp.22.1.79.

APHA 1998. Standard methods for the examination of water and wastewater, $20^{\text {th }}$ edn. American Public Health Association, Washington DC, USA.

Areerat, S. 1987. Clarias culture in Thailand. Aquaculture, 63: 355-362. DOI: 10.1016/0044-8486(87)90084-6.

Ariole, O. 2012. The effect of indigenous probiotics on egg hatchability and larval viability of Clarias gariepinus. An Interdisc. J Appl Sci., 7(1): 81-88. http://dx.doi.org/10.41 36/ambi-agua.712.

Avella, M. A., Gioacchini, G., Decamp, O., Makridis, P., Bracciatelli, C. and Carnevali, O. 2010. Application of multi-species of Bacillus in seabream larviculture. Aquaculture, 305: 12-19. DOI: 10.1016/j.aquaculture. 20 10.03.029.

Balcazar, J. L., de Blas, I., Ruiz-Zarzuela, I., Cunningham, D., Vendrell, D. and Muzquiz, J. L. 2006. The role of probiotics in aquaculture. Vet. Microbiol., 114: 173-186. DOI: 10.1016/j.vetmic.2006.01.009.

Behera, D. P. and Nayak, L. 2011. Role of probiotics in sustainable shrimp farming along Balasore coast, Orissa. The Bioscan, 6(1): 97-102. doi:10.1017/S1755267214001250(IF-1.0).

Bernfeld, P. 1955. Amylase $\alpha$ and $\beta$. In: Colowick, S. P. and Kaplan, N. O. (Eds.), Methods in enzymology. Academic Press Inc., New York, USA, 1: 149-158.

Bradford, M. M. 1976. Rapid and sensitive method for the quantitation of microgram quantities of protein utilising the principle of protein-dye binding. Animal. Biochem., 72: 248-254. DOI: 10.1006/abio.1976.9999.

Seenivasan, P. S. B., Radhakrishnan, S. and Muralisankar, T. 2012. Effects of probiotics on survival, growth and biochemical constituents of freshwater prawn Macrobrachium rosenbergii post-larvae. Turk. J. Fish Aquat. Sci., 12: 331-338. DOI: 10.4194/1303-2712-v12_2 19.

Cherry, I. S. and Crandall, L. A. Jr. 1932. The specificity of pancreatic lipase: its appearance in blood after pancreatic injury. Am. J. Physiol.,100: 266-273.

Cutting, S. M. 2011. Bacillus probiotics. Food Microbiol., 28: 214-220. doi: 10.1016/j.fm.2010.03.007.

Faramarzi, M., Hojatollah Jafaryan, Amin Farahi, Boloki, M. L. and Iranshahi, A. F. 2011. The effects on growth and survival of probiotic Bacillus spp. fed to Persian sturgeon (Acipencer persicus) larvae. AACL Bioflux, 4: 10-14.

Farzanfar, A. 2006. The use of probiotics in shrimp aquaculture. FEMS Immunol. Med. Microbiol., 48: 149-158. DOI: 10.1 111/j.1574-695X.2006.00116.x.

Hai, N. V. 2015a. Research findings from the use of probiotics in tilapia aquaculture: A review. Fish Shellfish Immunol., 45: 592-597. doi: 10.1016/j.fsi.2015.05.026.
Hai, N. V. 2015b. The use of probiotics in aquaculture. J. Appl. Microbiol., 119: 917-935. doi: 10.1111/jam.12886.

Keysami, M. A., Saad, C. R., Sijam, K., Daud, H. M. and Alimon, A. R. 2007. Effect of Bacillus subtilis on growth development and survival of larvae Macrobrachium rosenbergii (de Man). Aquac. Nutr., 13: 131-136. DOI: 10. 1111/j.1365-2095.2007.00463.x.

Keysami, M. A., Mohammadpour, M. and Saad, C. R. 2012. Probiotic activity of Bacillus subtilis in juvenile freshwater prawn, Macrobrachium rosenbergii (de Man) at different methods of administration to the feed. Aquac. Int., 20: 499-511. DOI 10.1007/s10499-011-9481-5.

Kumar, N. R., Raman, R. P., Jadhao, S. B., Brahmchari, R. K., Kundan, K. and Dash, G. 2013. Effect of dietary supplementation of Bacillus licheniformis on gut microbiota, growth and immuneresponse in giant freshwater prawn, Macrobrachium rosenbergii (de Man, 1879). Aquac. Int., 21: 387-403. DOI: 10.1007/s10499-01 2-9567-8.

Kumar, B. and Ghosh, U. K. 2016. Isolation and biochemical characterisation of soil inhabiting Lactobacillus species MTCC 10093. The Bioscan, 11(1): 169-172. www. thebioscan.in/Journals_PDF/11133\%20BINOD\%20 KUMAR.pdf

Liu, K. F., Chiu, C. H., Shiu, Y. L., Cheng, W. and Liu, C. H. 2010. Effects of the probiotic, Bacillus subtilis E20, on the survival, development, stress tolerance, and immune status of white shrimp, Litopenaeus vannamei larvae. Fish Shellfish Immunol., 28: 837-844. doi: 10.1016/j.fsi. 2010.01.012.

Martinez Cruz, P., Ibanez, A. L., Monroy Hermosillo, O. A. and Ramirez Saad, H. C. 2012. Use of probiotics in aquaculture. ISRN Microbiol., p. 13. doi: 10.5402/2012/916845.

Moriarty, D. J. W. 1996. Microbial biotechnology: a key ingredient for sustainable aquaculture. Infofish Int., 4: 29-33.

Moriarty, D. 1998. Control of luminous Vibrio species in penaeid aquaculture ponds. Aquaculture, 164: 351-358. DOI: 10.10 16/S0044-8486(98)00199-9.

Nayak, S. K. 2010. Probiotics and immunity: A fish perspective. Fish Shellfish Immunol., 29: 2-14. DOI: 10.1016/j.fsi.20 10.02.017

Nihan A., Alize Gokvardar, C. S., Fatih, B., Deniz, C., Sukru, Y., Okan Kamac, H., Kursat, F. and Sahin, S. 2013. Effects of probiotic (Bacillus sp.) supplementation during larval development of gilthead seabream (Sparus aurata, L.) Turk. J. Fish Aquat. Sci., 13: 407-414. DOI: 10.4194/13032712-v13_3_03.

Nimrat, S., Suksawat, S., Boonthai, T. and Vuthiphandchai, V. 2012a. Potential Bacillus probiotics enhance bacterial numbers, water quality and growth during early development 
of white shrimp (Litopenaeus vannamei). Vet. Microbiol., 159: 443-450. doi: 10.1016/j.vetmic.2012.04.029.

Nimrat, S., Tanutpongpalin, P., Sritunyalucksana, K., Boonthai, T. and Vuthiphandchai, V. 2012b. Enhancement of growth performance, digestive enzyme activities and disease resistance in black tiger shrimp (Penaeus monodon) postlarvae by potential probiotics. Aquac. Int., 21: 655-666.

Ninawe, A. S. and Selvin, J. 2009. Probiotics in shrimp aquaculture: avenues and challenges. Crit. Rev. Microbiol., 35 : 43-66. DOI: 10.1080/10408410802667202

Ramakrishnan, C. M, Haniffa, M. A. and Jeya Sheela, P. 2015. Effect of probiotics on survival and growth of Heteropneustes fossilis. Int. J. Pharma Res. Health Sci., 3: 784-793.www.pharmahealthsciences.net/pdfs/volume3issue3/16_vol3_issue3_MS_15153.pdf.

Rao, G. R. M., Tripathi, S. D. and Sahu, A. K. 1994. Breeding and seed production of the Asian catfish Clarias batrachus (Lin.). ICAR-Central Institute of Freshwater Aquaculture, Bhubaneswar, India, 5 pp.

Sahoo, S. K., Giri, S. S. and Chandra, S. 2008. Rearing performance of Clarias batrachus larvae: Effect of age at stocking on growth and survival during fingerling production. Aquaculture, 280: 158-160. DOI: 10.1016/j. aquaculture.2008.05.020.

Sinha, M., Mahapatra, B. K., Saha, D. and Mitra, N. J. 2014. Mass scale seed production of magur, Clarias batrachus at farm level through improvised modifications. Int.. J. Fish Aquat. Stud., 2(2): 210-214.

Sorgeloos, P., Lavens, P., Leger, P., Tackaert, W. and Versichele, D. 1986. Manual for the culture and use of brine shrimp Artemia in aquaculture. Artemia Reference Center, Ghent, Begium, 319 pp.

Sumathi, C., Dillibabu, V., Madhuri, D. K., Priya, D. M., Nagalakshmi, C. and Sekaran, G. 2014. Dietary inclusion of protease producing novel Pontibacter spp. and Bacillus megaterium as a probiotic enhances immune responses in Labeo rohita. Pak. J. Biol. Sci., 17: 451-461. DOI: 10.3923/ pjbs.2014.451.461.

Sun, Y. Z., Yang, H. L., Ma, R. L. and Lin, W.Y. 2010. Probiotic applications of two dominant gut Bacillus strains with antagonistic activity improved the growth performance and immune responses of grouper Epinephelus coioides. Fish Shellfish Immunol., 29: 803-809. doi: 10.1016/j.fsi. 2010.07.018.
Suzer, C., Coban, D., Kamaci, H. O., Saka, S., Firat, K., Otgucuoglu, O. and Kucüksari, H. 2008. Lactobacillus spp. bacteria as probiotics in gilthead seabream (Sparus aurata, L.) larvae: Effects on growth performance and digestive enzyme activities. Aquaculture, 280(1-4): 140-145. DOI: 10.1016/j.aquaculture.2008.04.020.

Thakur, N. K. and Das, P. 1986. Synopsis of biological data on magur, Clarias batrachus (Linnaeus, 1758). Bulletin of the Central Inland Fisheries Research Institute, 41: 1-42.

Verschuere, L., Rombaut, G., Sorgeloos, P. and Verstraete, W. 2000. Probiotic bacteria as biological control agents in aquaculture. Microbiol. Mol. Biol Rev.., 64: 655-671. https://www.ncbi.nlm.nih.gov/pmc/ articles/PMC99008/.

Walker, W. A. and Duffy, L. C. 1998. Diet and bacterial colonization: role of probiotics and prebiotics. J. Nutr. Biochem., 9(12): 668-675. DOI: 10.1016/S0955-2863(98) 00058-8

Wang, Y. B., Tian, Z. Q., Yao, J. T. and Li, W. F. 2008. Effect of probiotics, Enteroccus faecium, on tilapia (Oreochromis niloticus) growth performance and immune response. Aquaculture, 277: 203-207. DOI: 10.1016/j. aquaculture.2008.03.007.

Yanbo, W. and Zirong, X. 2006. Effect of probiotics for common carp (Cyprinus carpio) based on growth performance and digestive enzyme activities. Anim. Feed Sci. Technol., 127: 283-292. DOI: 10.1016/j.anifeedsci.2005.09.003.

Zhou, X., Wang, Y. and Li, W. 2009. Effect of probiotic on larvae shrimp (Penaeus vannamei) based on water quality, survival rate and digestive enzyme activities. Aquaculture, 287: 349-353. DOI: 10.1016/j.aquaculture.2008.10.046.

Zhou, X., Tian, Z., Wang, Y. and Li, W. 2010. Effect of treatment with probiotics as water additives on tilapia (Oreochromis niloticus) growth performance and immune response. Fish. Physiol. Biochem., 36: 501-509. doi: 10.1007/s10695-0099320-z.

Ziaei-Nejad, S., Rezaei, M. H., Takami, G. A., Lovett, D. L., Mirvaghefi, A.R. and Shakouri, M. 2006. The effect of Bacillus spp. bacteria used as probiotics on digestive enzyme activity, survival and growth in the Indian white shrimp Fenneropenaeus indicus. Aquaculture, 252: 516-524.https://doi.org/10.1016/j.aquaculture.2005.07.021. 